\title{
Does the persistence of sweet chestnut depend on cultural inputs? Regeneration, recruitment, and mortality in Quercus- and Castanea-dominated forests
}

\author{
Fernando Silla ${ }^{1}$ - Álvaro Camisón ${ }^{2} \cdot$ Andrea Solana $^{1} \cdot$ Héctor Hernández ${ }^{1}$ - Guillermo Ríos ${ }^{1} \cdot$ Miguel Cabrera $^{1}$. \\ Dámaris López ${ }^{1} \cdot$ Albert Morera-Beita $^{3}$
}

Received: 19 January 2018 / Accepted: 21 September 2018 / Published online: 19 November 2018

(C) INRA and Springer-Verlag France SAS, part of Springer Nature 2018

\begin{abstract}
- Key message Quercus secondary forests show a gradual transition toward mixed forests, with sweet chestnut (Castanea sativa) becoming increasingly abundant in the western Spanish Central System. Additionally, in chestnut-dominated stands, it shows a certain resistance to competitive displacement by Quercus pyrenaica. Our results partially refute the traditional view that $C$. sativa is unable to recruit in the absence of cultural inputs.

- Context Sweet chestnut, Castanea sativa, is a component of European broadleaf forests and is one of the most managed trees. Due to a reduction in cultural inputs, chestnut-dominated stands tend to be invaded by other species, and it is unclear how chestnut is able to persist in natural mixed forests.

- Aims Our work aimed to identity the main factors that limit the establishment of $C$. sativa and to analyze the recruitment and mortality processes of $C$. sativa trees.

- Methods The age, growth ring patterns, regeneration density, and the spatial structure of trees and saplings in 11 plots in the Spanish Central System were analyzed.

- Results Chestnut seedling density increased with C. sativa basal area, but transition toward the sapling stage appeared limited owing to light availability. In Quercus pyrenaica secondary forests, sparse canopies did not constrain chestnut regeneration, and in old chestnut stands, C. sativa showed a certain resistance to competitive displacement. By contrast, mixed young coppices showed a high mortality, most likely due to competition with other vigorous resprouters.

- Conclusion Quercus secondary forests showed a gradual transition toward mixed forests with sweet chestnut becoming increasingly more abundant. In old stands, $C$. sativa is likely to persist under a gap-phase mode of regeneration. Our results partially refute the traditional view that $C$. sativa is unable to recruit in the absence of cultural inputs.
\end{abstract}

Keywords Chestnut recruitment $\cdot$ Quercus pyrenaica $\cdot$ Secondary forest $\cdot$ Tree mortality $\cdot$ Forest succession

\section{Handling Editor: Andreas Bolte}

Contribution of the co-authors Fernando Silla: sampling design, field work, data analysis, writing of paper

Álvaro Camisón, Andrea Solana, Héctor Hernández, Guillermo Ríos, Miguel Cabrera, Dámaris López: field work, processing of samples, data analysis, paper revision

Albert Morera: field work, paper revision

\section{Fernando Silla}

fsilla@usal.es

1 Area of Ecology, Faculty of Biology, University of Salamanca, Salamanca, Spain
2 Area of Agroforestry, University of Extremadura (University Center of Plasencia), Badajoz, Spain

3 Laboratory of Applied Tropical Ecology, National University of Costa Rica, Heredia, Costa Rica 


\section{Introduction}

The sweet chestnut (Castanea sativa Mill.) is one of the most managed trees in Europe and covers more than 2.5 million ha (Amorini et al. 2000; Scarascia-Mugnozza et al. 2000; Conedera et al. 2004, 2016; San Roman Sanz et al. 2013). Palynological, anthracological, and macrofossil evidence indicates that $C$. sativa survived the main glacial events that occurred in favorable refuges, ranging from the west of the Iberian Peninsula to the east coast of the Black Sea-Caucasus region (Fineschi et al. 2000; Conedera et al. 2004; Krebs et al. 2004), and it is considered a component of European temperate broadleaf forests (Conedera et al. 2016). The cultivation of C. sativa has expanded its natural range, and sweet chestnut has become a widespread element of the landscape in most of the Mediterranean basin and southern parts of Central Europe (Scarascia-Mugnozza et al. 2000; Conedera and Krebs 2008; Morales-Molino et al. 2015). Socioeconomic factors and the spread of diseases, such as chestnut blight (Cryphonectria parasitica) and ink disease (Phythophthora spp.), has reduced the interest in the management of these forests (Amorini et al. 2000; Gallardo 2001; Conedera and Krebs 2008; San Roman Sanz et al. 2013; Seijo et al. 2015). As a result, chestnut stands tend to become invaded by other species and to evolve toward mixed deciduous forests (Conedera et al. 2000, 2001, 2016; Zlatanov et al. 2013). However, in recent decades, naturally occurring hypovirulent strains of $C$. parasitica with attenuated pathogenesis has allowed $C$. sativa to become again a viable species for timber and nut production (Milgroom and Cortesi 2004; Waldboth and Oberhuber 2009; Zlatanov et al. 2015). Also, a large amount of naturally occurring genetic variation resistant to ink disease has been detected, suggesting the potential of breeding programs to improve the health status of C. sativa populations (Robin et al. 2006).

The regeneration dynamics of $C$. sativa has not been studied in depth, and it is unclear how C. sativa recruitment occurs within natural forests. Most of the recruitment dynamics have been inferred from studies carried out on managed forests, where $C$. sativa trees exhibit vigorous sprouting after being cut (Cutini 2001; Giudici and Zingg 2005). The few studies that have addressed $C$. sativa seedling dynamics found that low shade tolerance limits successful recruitment under close canopies, where the low level of regeneration of $C$. sativa seedlings is outcompeted by more shade-tolerant species (Pridnya et al. 1996; Sevilla 2008; Pividori et al. 2005; Zlatanov et al. 2013). Furthermore, the lack of pristine mixed temperate forests in the Mediterranean basin, due to centuries of human intervention, is a relevant limitation in the study of C. sativa regeneration dynamics (Scarascia-Mugnozza et al. 2000; Conedera et al. 2016). Despite the various limitations and owing to the need for knowledge regarding ecological forestry, we established the following hypothesis. (1) Seedling recruitment of $C$. sativa is mainly limited by seed production, and therefore, we expect to find a positive relationship between seedling abundance and basal area and/or tree density of $C$. sativa. (2) Transition from seedling to sapling stage and sapling growth are a light-limited process, and we expect a higher $C$. sativa sapling/seedling ratio and sapling-growth rate in the forest stands with higher light availability in the understory. (3) Tree establishment is also lightlimited and linked to canopy opening. This time, we establish that $C$. sativa dominance in forests is mainly linked to recruitment after disturbance, and in the absence of cultural inputs, reaching into the main canopy is limited by light availability and competition with other tree species. (4) Tree mortality is a non-random-spatial process mainly influenced by competition, and we expect to find $C$. sativa dead trees more frequently closer to other trees than what could be expected if they came from a completely randomized spatial distribution. To test these hypotheses, age structure, growth ring patterns, regeneration density, and spatial structure of trees and saplings were analyzed in Quercus- and Castanea-dominated forests in the Spanish Central System.

\section{Material and methods}

\subsection{Study area}

The study region is located in the mountain range of the Sierra de Francia-Quilamas, in the west subdivision of the Central System, Spain. Within this region, two areas were selected: the Quilamas range (900-1423 m a.s.1.) and the slopes of the Alagón river basin (500-900 m a.s.l.). Annual precipitation varies between 1000 and $1400 \mathrm{~mm}$ in the Quilamas range and between 1100 and $1300 \mathrm{~mm}$ in the Alagón river basin. Both have a typical Mediterranean period of low precipitation during July and August. The mean annual temperature is between 10 and $12.5^{\circ} \mathrm{C}$ for the Quilamas range and around $14-15^{\circ} \mathrm{C}$ for the Alagón river basin.

Chestnut blight was first time detected in the early 2000s and still remains isolated within a small area in the Sierra de Francia-Quilamas range (García and Monte 2005; Zamora et al. 2012). Ink disease has also been reported in the region (García and Monte 2005).

\subsection{Sampling design and data collection}

We selected six stands dominated by $C$. sativa (CDF: Castanea-dominated forests), encompassing three young abandoned coppices (CDF1-3) and three old coppices converted by thinning to high forests (CDF4-6), as well as five nearby $Q$. pyrenaica secondary forests (QSFs). Abandoned coppices were not managed after last clear-cutting (1983, 1954 and 1954 in CDF1, CDF2 and CDF3, respectively; Dirección General de Montes, Caza y Pesca Fluvial 1967), 
showing between 7 and 12 shoots ( $>2 \mathrm{~m}$ height) per chestnut stool. The $C$. sativa trees in one abandoned coppice (CDF2) had scars in their bark, which was the result of a previous undated fire. One plot was established in each stand. Plot size was variable in the areas, ranging between 400 and $1200 \mathrm{~m}^{2}$, because of differences in tree density between stands (Table 1). An initial $400 \mathrm{~m}^{2}$ plot was located and was sequentially expanded to 900 or $1200 \mathrm{~m}^{2}$ until at least $35-40$ trees were available for tree coring and subsequent dendrochronological and forest disturbance analysis (Veblen 1992). All plots were square-shaped and their sides were oriented in the directions of the cardinal points. All data were collected between October 2011 and June 2016.

All trees (live and dead) and saplings in each plot were recorded. Seedling regeneration was estimated using 20 randomly located sampling units of $4 \mathrm{~m}$ long and $0.25 \mathrm{~m}$ wide in each plot. We used these long, narrow sampling units in order to reduce some of the variance due to the clumped seedling distribution of $Q$. pyrenaica observed at many plots (Krebs 1999). Trees were defined as individuals with a diameter at breast height $(\mathrm{dbh}) \geq 5 \mathrm{~cm}$; saplings as individuals with a dbh $<5 \mathrm{~cm}$ and height $>200 \mathrm{~cm}$, and seedlings as individuals $<$ $200 \mathrm{~cm}$ in height. Additionally, positions of trees and saplings were located to the nearest centimeter using measuring tapes that were aligned with the sides of the plots, providing $\mathrm{X}$ and Y coordinates for them.

\subsubsection{Photosynthetic photon lux measurements}

A pair of QSO-S photon flux sensors (Decaegon Devices, Inc., USA) was positioned randomly at a height of $30 \mathrm{~cm}$ above-ground in each stand to measure the photosynthetic photon flux (PPF) in $\mu \mathrm{mol} \mathrm{m} \mathrm{m}^{-2} \mathrm{~s}^{-1}$. The PPF was recorded each minute using an EM50 digital data logger (Decaegon Devices, Inc., USA). PPF data were taken per stand on clear-sky days during 2 days (in a different position each day) from June to September; however, only the data taken between 11:00 and 16:00 solar time were used. To calculate the percentage of light that reached the understory, the PPF was measured in a nearby sun-exposed site on consecutive days.

\subsubsection{Sapling primary growth rate}

In order to obtain information about the primary growth rates of advanced regeneration, 7 and 10 C. sativa saplings (2-3 per plot) of seed origin from the CDF and QSF stands, respectively, were randomly selected. Saplings were cut at ground level and taken to the laboratory. Sapling stems were dissected each $20 \mathrm{~cm}$ from the base to the tip into stem-cross sections. Next, cross sections were manually sanded until annual rings were clearly visible for counting. Primary growth rates were estimated through the relationship between the age of the sapling

Table 1 Summary of plot characteristics

\begin{tabular}{|c|c|c|c|c|c|c|c|}
\hline Plot & $\begin{array}{l}\text { Geographic } \\
\text { coordinates }\end{array}$ & $\begin{array}{l}\text { Plot } \\
\text { size }\left(\mathrm{m}^{2}\right)\end{array}$ & $\begin{array}{l}\text { Elevation } \\
\text { (m a.s.1.) }\end{array}$ & Orientation & $\begin{array}{l}\text { Plot density } \\
\text { (living trees/ha) }\end{array}$ & $\begin{array}{l}\text { Cs dead } \\
\text { trees }(\%)\end{array}$ & $\begin{array}{l}\text { Maximum/ } \\
\text { mean tree } \\
\text { age (years) }\end{array}$ \\
\hline QSF1 & $\begin{array}{l}40^{\circ} 34^{\prime} 33^{\prime \prime} \mathrm{N} \\
05^{\circ} 57^{\prime} 24^{\prime \prime} \mathrm{W}\end{array}$ & 400 & 1177 & $\mathrm{~N}$ & 1550.0 & 0.0 & $54 / 41$ \\
\hline QSF2 & $\begin{array}{l}40^{\circ} 34^{\prime} 40^{\prime \prime} \mathrm{N} \\
05^{\circ} 56^{\prime} 19^{\prime \prime} \mathrm{W}\end{array}$ & 400 & 1000 & $\mathrm{~N}$ & 1475.0 & 0.0 & $53 / 48$ \\
\hline QSF3 & $\begin{array}{l}40^{\circ} 33^{\prime} 54^{\prime \prime} \mathrm{N} \\
05^{\circ} 54^{\prime} 48^{\prime \prime} \mathrm{W}\end{array}$ & 900 & 998 & $\mathrm{~N}$ & 666.7 & 0.0 & $65 / 53$ \\
\hline QSF4 & $\begin{array}{l}40^{\circ} 34^{\prime} 01^{\prime \prime N} \\
05^{\circ} 56^{\prime} 56^{\prime \prime} \mathrm{W}\end{array}$ & 400 & 1136 & $\mathrm{~N}$ & 950.0 & 0.0 & $68 / 53$ \\
\hline QSF5 & $\begin{array}{l}40^{\circ} 34^{\prime} 00^{\prime \prime} \mathrm{N} \\
05^{\circ} 54^{\prime} 55^{\prime \prime} \mathrm{W}\end{array}$ & 400 & 1005 & N-NW & 2050.0 & 0.0 & $73 / 57$ \\
\hline CDF1 & $\begin{array}{l}40^{\circ} 34^{\prime} 42^{\prime \prime} \mathrm{N} \\
05^{\circ} 56^{\prime} 21^{\prime \prime} \mathrm{W}\end{array}$ & 400 & 1006 & NW & 2300.0 & 16.0 & $31 / 26$ \\
\hline CDF2 & $\begin{array}{l}40^{\circ} 29^{\prime} 30^{\prime \prime} \mathrm{N} \\
05^{\circ} 55^{\prime} 21^{\prime \prime} \mathrm{W}\end{array}$ & 900 & 640 & $\mathrm{~N}$ & 2166.7 & 31.6 & $60 / 29$ \\
\hline CDF3 & $\begin{array}{l}40^{\circ} 29^{\prime} 26^{\prime \prime} \mathrm{N} \\
05^{\circ} 55^{\prime} 06^{\prime \prime} \mathrm{W}\end{array}$ & 900 & 625 & $\mathrm{~N}$ & 1833.3 & 75.4 & $63 / 44$ \\
\hline CDF4 & $\begin{array}{l}40^{\circ} 34^{\prime} 01^{\prime \prime} \mathrm{N} \\
05^{\circ} 54^{\prime} 56^{\prime \prime} \mathrm{W}\end{array}$ & 900 & 1000 & N-NW & 766.7 & 6.8 & $119 / 57$ \\
\hline CDF5 & $\begin{array}{l}40^{\circ} 34^{\prime} 25^{\prime \prime} \mathrm{N} \\
05^{\circ} 56^{\prime} 53^{\prime \prime} \mathrm{W}\end{array}$ & 900 & 1090 & $\mathrm{~N}$ & 688.9 & 6.3 & $115 / 53$ \\
\hline CDF6 & $\begin{array}{l}40^{\circ} 34^{\prime} 24^{\prime \prime} \mathrm{N} \\
05^{\circ} 57^{\prime} 17^{\prime \prime} \mathrm{W}\end{array}$ & 1200 & 1150 & $\mathrm{NE}$ & 708.3 & 10.5 & $124 / 64$ \\
\hline
\end{tabular}

C. sativa (Cs) dead trees are shown as a percentage in relation to all $C$. sativa trees

QSF Quercus secondary forest, CDF Castanea-dominated forest 
(number of tree-rings at the base) and the number of tree-rings in each 20-cm-distant cross section.

\subsubsection{Dendrochronological analysis}

Increment cores from all trees were extracted with Pressler increment borers (Häglof, Sweden) at 0.3-0.4 m aboveground level to obtain the most accurate age for each tree (Veblen 1992) and at $0.6 \mathrm{~m}$ when the tree centers were rotten. A total of 972 cores were collected (one core per tree). Increment cores were mounted and sanded following the procedure established by Stokes and Smiley (1968), and the annual rings were counted using a stereomicroscope (SMZ800, Nikon, Japan). When the cores did not reach the pith, the number of rings to the center was estimated using the geometric procedure described by Duncan (1989). If the center was rotten, the rings counted in the non-rotten section of the core were considered as the minimum age for that tree. Cores were scanned at 2000 dpi resolution (Perfection V550, Epson, Japan), and tree-ring widths were measured with a $0.01-\mathrm{mm}$ resolution on the scanned JPG images using the software CooRecorder 7.6 (Cybis, Sweden). The visual and statistical cross-dating of the tree-ring width series was done and checked using the software CDendro 7.6 (Cybis, Sweden) and Cofecha (Holmes 1983), respectively.

\subsubsection{Forest disturbance}

Forest disturbances were inferred by radial-growth release detection methods. Specifically, the radial-growth averaging criteria (Nowacki and Abrams 1997) were applied by comparing the medians of a consecutive 10-year period. The threshold for considering a release was set up to a $50 \%$ relative growth change over 5 years.

\subsection{Statistical analysis}

We modeled relationships between forest variables (tree density, basal area, and percentage of incident light) and between age and height of $C$. sativa saplings using the most suitable simple regression model (lineal, exponential, power and/or logarithmic functions). Relationships between seedling abundance and forest variables were modeled using the binomial negative regression of generalized linear models (GLMs). In QSF stands, we also tested the relationship between $C$. sativa tree abundance and the maximum age of $Q$. pyrenaica trees (as a substitute of stand initiation age) using the same GLM model. Owing to the lack of normality of the non-transformed and transformed data, we used the non-parametric Wilcoxon/ Kruskal-Wallis tests to evaluate statistical differences in seedling abundance between tree species and in percentage of light that reached the understory between QSF and CDF stands. These analyses were performed using vegan package under
$\mathrm{R}$ environment ( $\mathrm{R}$ Development Core Team 2013). The $\mathrm{R}$ software package TRADER (Altman et al. 2014) was used to infer forest disturbances through radial-growth releases.

For each plot, the spatial relationship between saplings and trees of $C$. sativa was analyzed using the bivariate O-ring statistic using the toroidal shift model (Wiegand and Moloney 2014). In the case of two different age cohorts of $C$. sativa trees, the spatial distribution of the youngest in relation to the oldest cohort was also determined. O-ring statistic was derived from the pair correlation function, which was defined as the expected number of points of one variable (e.g., saplings) between the larger and smaller radius of a ring of fixed width, at increasing distances from an arbitrary point of the other variable (e.g., trees), divided by the intensity $\lambda$ of the pattern (Diggle 2003; Wiegand and Moloney 2014). In addition, $C$. sativa mortality was analyzed using the random labeling model, where locations of all $C$. sativa trees were maintained, and the alive/dead condition was randomly assigned (Wiegand and Moloney 2014). Lastly, we performed a trivariate analysis with the mark correlation function to test if C. sativa mortality was influenced by the presence of other species, and at what spatial scales (de la Cruz et al. 2008; Wiegand and Moloney 2014). To evaluate the significance of the spatial statistics under the considered null model, 95\% simulated envelopes were generated using 199 MonteCarlo simulations. The fifth highest and lowest values of the 199 iterated functions were chosen to obtain the upper and lower values of the envelopes, respectively (Wiegand and Moloney 2014). Also, the goodnessof-fit (GoF) test was used to provide expected type I error rates, selecting a distance interval of $0-10 \mathrm{~m}$ to assess departures from the null model (Diggle 2003; Loosmore and Ford 2006). All spatial analyses were performed using the 2014 version of the Programita software (Wiegand and Moloney 2014).

\section{Results}

\subsection{Light conditions}

The percentage of incident light that reached the understory was significantly higher in QSF than in CDF $(18.6 \pm 2.8$ and $5.1 \pm$ 2.5 , mean \pm se for QSF and CDF, respectively; $p=0.0025, n=$ 11). The percentage of incident light was significantly inversely related to the basal area of $C$. sativa trees $(\log (\mathrm{y})=2.54-0.03 \times$, $\mathrm{n}=11, p=0.020$ ), but not with the total basal area of all tree species $(\log (\mathrm{y})=3.28-0.04 \times, \mathrm{n}=11, p=0.161)$.

\subsection{Regeneration abundance and sapling age-height models}

The abundance of $C$. sativa and $Q$. pyrenaica seedlings were positively correlated with $C$. sativa and $Q$. pyrenaica tree basal areas across the stands, respectively (Table 2). But only $Q$. pyrenaica seedling abundance was significantly correlated 
with tree density and percentage of incident light that reached the understory (Table 2). However, there was a positive linear relationship between the $C$. sativa ratio of saplings per seedling with the percentage of incident light across stands, but not for the Quercus species (Table 2). In QSF stands, although $C$. sativa seedling regeneration was significantly lower than $Q$. pyrenaica $(p<0.001, n=5$, Table 3$)$, there were no significant differences in sapling abundance $(p=0.1991, n=5$, Table 3). In the older CDF4-6 stands, $C$. sativa showed higher abundance of seedlings ( $p=0.0463, n=3$, Table 3 ) and saplings ( $p=0.0369, n=3$, Table 3 ) than $Q$. pyrenaica. By contrast, in younger CDF1-3 stands, there were no significant differences in seedling ( $p=0.4029, n=3$, Table 3 ) or sapling abundance ( $p=0.1051, n=3$, Table 3 ) between $C$. sativa and Quercus species.

In relation to age-height growth models for $C$. sativa saplings from seed origin (Fig. 1), the best adjustment for QSF followed an exponential model $\left(R^{2}=0.81 ; p<0.0001 ; n=\right.$ $11)$, whereas CDF followed a linear model $\left(R^{2}=0.88\right.$; $p<0.0001 ; n=7)$.

\subsection{Age structures and radial-growth releases}

QSF plots were characterized by a single cohort of trees with no recruitment of $Q$. pyrenaica young trees during the last few decades (Fig. 2a-e). Only C. sativa was recruited in small numbers, and the number of $C$. sativa trees was positively and significantly related with the age of the oldest Q. pyrenaica tree (negative binomial GLM, $p=0.004, n=5$, $\mathrm{AIC}=21.7$ ) in the QSF plots.

Except for CDF1, broad and multiage age structures dominated by $C$. sativa characterized together with other tree species the CDF plots (Fig. 3). These stands showed complex structures which varied from distinct age cohorts to continuous tree recruitment patterns. CDF2, CDF4, and CDF6 showed multiage structures where recruitment waves in $C$. sativa trees was produced just after synchronous radial-growth releases of the older trees in the $54 \%, 50 \%$, and $76.9 \%$, respectively (Fig. $4 \mathrm{~g}, \mathrm{j}, \mathrm{k}$ ). Although CDF5 showed a complex multiage pattern, tree recruitment was not associated to any previous synchronous release in tree growth. However, $38.5 \%$ of the trees in CDF5 showed asynchronous individual radial-growth releases between 1924 and 1997. CDF3 showed continuous recruitment after stand initiation with a broad and left-skewed age structure dominated by Quercus spp. (Fig. 3c). No synchronous release in the radial-growth pattern was evident in CDF3 (Fig. $4 \mathrm{~h}$ ), but $19 \%$ of all trees showed individual growth releases between 1966 and 2000. The youngest CDF1 showed a narrow and left-skewed age distribution, and no release in the radial-growth pattern was found.

C. sativa mortality was low in the older stands but was from moderate to high in the younger coppices, especially in the CDF3 plot where $75.4 \%$ of all $C$. sativa trees were dead (Table 1).

\subsection{Bivariate and trivariate spatial patterns and tree mortality}

In the CDF stands, C. sativa saplings were independently distributed from trees at most of the distances analyzed, as confirmed by the GoF tests (Table 4). In the CDF stands, when two age cohorts were clearly distinguished, the young cohort was independently distributed from the old cohort (Table 4). C. sativa tree mortality was nil in the QSF stands, low in the old CDF stands, and from moderate to high in the young CDF stands (Table 1). When the distribution of dead C. sativa trees in relation to live trees in the overstory was analyzed in the young CDF stands, using the random labeling null model, the segregation of dead trees from live trees was found at short distances in CDF1, but up to $12-13 \mathrm{~m}$ in the plots with the highest mortality (Table 4). Trivariate analysis in CDF1 did not show that the proximity of $Q$. pyrenaica trees influenced the

Table 2 Regression models for seedling abundance (binomial negative models) and sapling/seedling ratio (linear models)

\begin{tabular}{|c|c|c|c|c|c|}
\hline Species & Model & Explained deviance (\%) & $\mathrm{R}^{2}$ & AIC & $p$ \\
\hline \multirow[t]{4}{*}{ C. sativa } & $\ln ($ seedling.abun $)=0.71+0.05 *($ BA.Cs $)$ & 47.8 & & 64.21 & $<0.001$ \\
\hline & $\ln ($ seedling. abun $)=1.45+0.01 *($ TD.Cs $)$ & 4.4 & & 71.20 & 0.181 \\
\hline & $\ln ($ seedling.abun $)=2.69-0.09 *(\%$ light $)$ & 19.3 & & 69.15 & 0.076 \\
\hline & sapling:seedling.ratio $=0.018+0.007 *(\%$ light $)$ & & 37.6 & & 0.045 \\
\hline \multirow[t]{4}{*}{ Q. pyrenaica } & $\ln ($ seedling.abun $)=1.23+0.15 *($ BA.Qp $)$ & 43.2 & & 98.56 & $<0.001$ \\
\hline & $\ln ($ seedling.abun $)=2.11+0.04 *($ TD.Qp $)$ & 26.9 & & 101.69 & 0.004 \\
\hline & $\ln ($ seedling.abun $)=1.99+0.13 *(\%$ light $)$ & 27.3 & & 101.50 & 0.009 \\
\hline & sapling:seedling.ratio $=0.0006+0.00007 *(\%$ light $)$ & & 7.38 & & 0.419 \\
\hline
\end{tabular}

Basal area (BA) and tree density (TD) of each species, and the percentage of understory light (\% light) used as independent variables

Cs C. sativa; $Q p$ Q. pyrenaica 
Table 3 Regeneration density per hectare (mean \pm standard error) of the main tree and tree-like species at each plot: $C$. sativa

\begin{tabular}{|c|c|c|c|c|c|c|c|c|c|c|c|c|c|}
\hline \multirow[t]{2}{*}{ Plot } & \multicolumn{7}{|l|}{ Seedlings/ ha } & \multicolumn{6}{|c|}{ Saplings/ha } \\
\hline & $\mathrm{Cs}$ & Qp & Qf & Qi & $\mathrm{Pa}$ & Ia & $\mathrm{Au}$ & Cs & $\mathrm{Qp}$ & Qf & $\mathrm{Pa}$ & Ia & $\mathrm{Au}$ \\
\hline QSF1 & $2070 \pm 544$ & $36,739 \pm 7722$ & - & - & $637 \pm 382$ & $637 \pm 382$ & - & 375 & - & - & - & - & - \\
\hline QFS2 & $637 \pm 334$ & $22,341 \pm 3775$ & - & - & - & - & - & 75 & 25 & - & - & - & - \\
\hline QFS3 & $1134 \pm 852$ & $39,600 \pm 8380$ & - & - & - & - & - & 44 & 178 & - & - & - & - \\
\hline QFS4 & $2000 \pm 941$ & $89,000 \pm 10,471$ & - & - & - & - & - & 225 & 200 & - & - & - & - \\
\hline QFS5 & $1500 \pm 819$ & $39,000 \pm 8010$ & - & - & - & - & - & 225 & 25 & - & - & - & - \\
\hline CDF1 & $1274 \pm 358$ & $3662 \pm 1748$ & - & - & $637 \pm 292$ & - & - & 425 & 25 & - & - & - & - \\
\hline CDF2 & - & - & $3333 \pm 1594$ & - & $1333 \pm 909$ & - & $10,667 \pm 2754$ & 444 & - & 78 & 22 & - & 78 \\
\hline CDF3 & - & $3500 \pm 2436$ & $6500 \pm 1957$ & $500 \pm 500$ & - & - & - & 33 & - & 67 & - & - & - \\
\hline CDF4 & $1756 \pm 425$ & - & - & - & $267 \pm 157$ & - & - & 155 & - & - & - & - & - \\
\hline CDF5 & $13,500 \pm 3719$ & - & - & - & $1000 \pm 1000$ & $11,500 \pm 4309$ & - & 322 & - & - & 122 & 11 & - \\
\hline CDF6 & $16,500 \pm 2927$ & $500 \pm 500$ & - & - & - & $5000 \pm 1701$ & - & 275 & - & - & - & 133 & - \\
\hline
\end{tabular}

Qp Q. pyrenaica, Qf Q. faginea, Qi Q. ilex, Pa Prunus avium, Ia Ilex aquifolium, Au Arbutus unedo

mortality of C. sativa overstory trees. However, in the CDF2 plot, trivariate analysis showed that dead C. sativa trees were less frequent than expected under a random process at distances beyond $10 \mathrm{~m}$ from another tree species (Table 4). In the CDF3 stand, trivariate analysis showed that dead $C$. sativa trees were more frequent at distances between 2 and $6 \mathrm{~m}$ from other trees species and less frequent at 11 and $14 \mathrm{~m}$ (Table 4).

\section{Discussion}

\subsection{Seedling and sapling dynamics}

Seedling regeneration is not related to light availability, but it increases with $C$. sativa basal area due to the greater availability

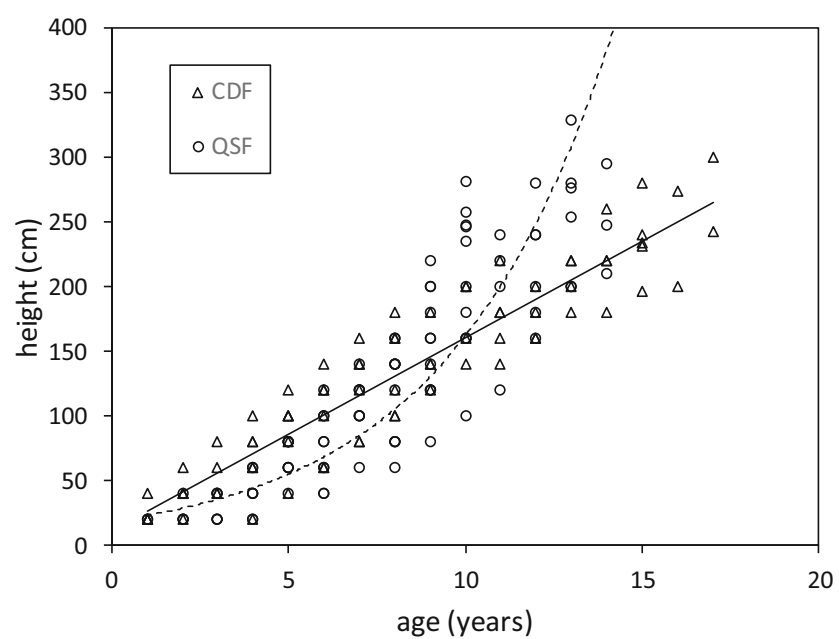

Fig. 1 Age-height growth models for C. sativa saplings from seed origin for QSF (circles, dashed line) and CDF (triangles, continuous line) stands of chestnuts produced and dispersed by barochory, with the mature CDF stands showing the highest densities of $C$. sativa seedlings (Pridnya et al. 1996; Gilland et al. 2012; Zlatanov et al. 2013). In the QSF stands, low seedling density appears mainly limited by seed dispersal, due to the heavy weight of chestnuts (Mujic et al. 2010). Although C. sativa is likely sciophilous at the very early seedling stage, canopy cover of QSF stands still intercepts $80 \%$ of the incident light. Besides, most of the plots are N or NW oriented, so the excess of light is not a limiting factor in seedling recruitment in the QSF plots. Potential $C$. sativa mother trees are commonly close to QSF sites (100-300 m away) but are always downhill, as chestnut stands are usually placed at the bottom of the slopes or small valleys. Although the dispersion syndrome of the Castanea genus has been minimally addressed (Vander Wall 2001), the Eurasian jay, Garrulus glandarius L., a common corvid in our study area, harvests small quantities of chestnuts, hiding them in the same manner as acorns (Holyoak 1968). Furthermore, this practice is likely the main dispersion vector for $C$. sativa in our study areas, where chestnuts are spread across several hundreds of meters away from the mother trees, as shown in other sites (Urbisz and Urbisz 2007). Despite seed limitation in QSF stands, C. sativa has higher sapling/seedling ratio than in CDF stands suggesting greater seedling survival and probability to promote to the sapling stage due to better light conditions, as shadowed understories are linked to high mortality at the seedling stage (Pridnya et al. 1996; Pividori et al. 2005; Zlatanov et al. 2013). Additionally, the thin canopies of QSF stands allowed increasing height growth with age in $C$. sativa saplings during the first years of establishment, whereas in the closed $\mathrm{CDF}$, canopies surviving $C$. sativa saplings showed a constant but slower height-growth rate. In the CDF stands, sapling distribution is independent of trees, as treefall gaps are still not common in these developing forests. However, sunflecks, brief 
Fig. 2 Age distributions in 5-year establishment classes of the QSF stands. Left panels and open bars: Q. pyrenaica; right panels and black solid bars: $C$. sativa. Note that the $y$-axis in the left and right panels has different scales

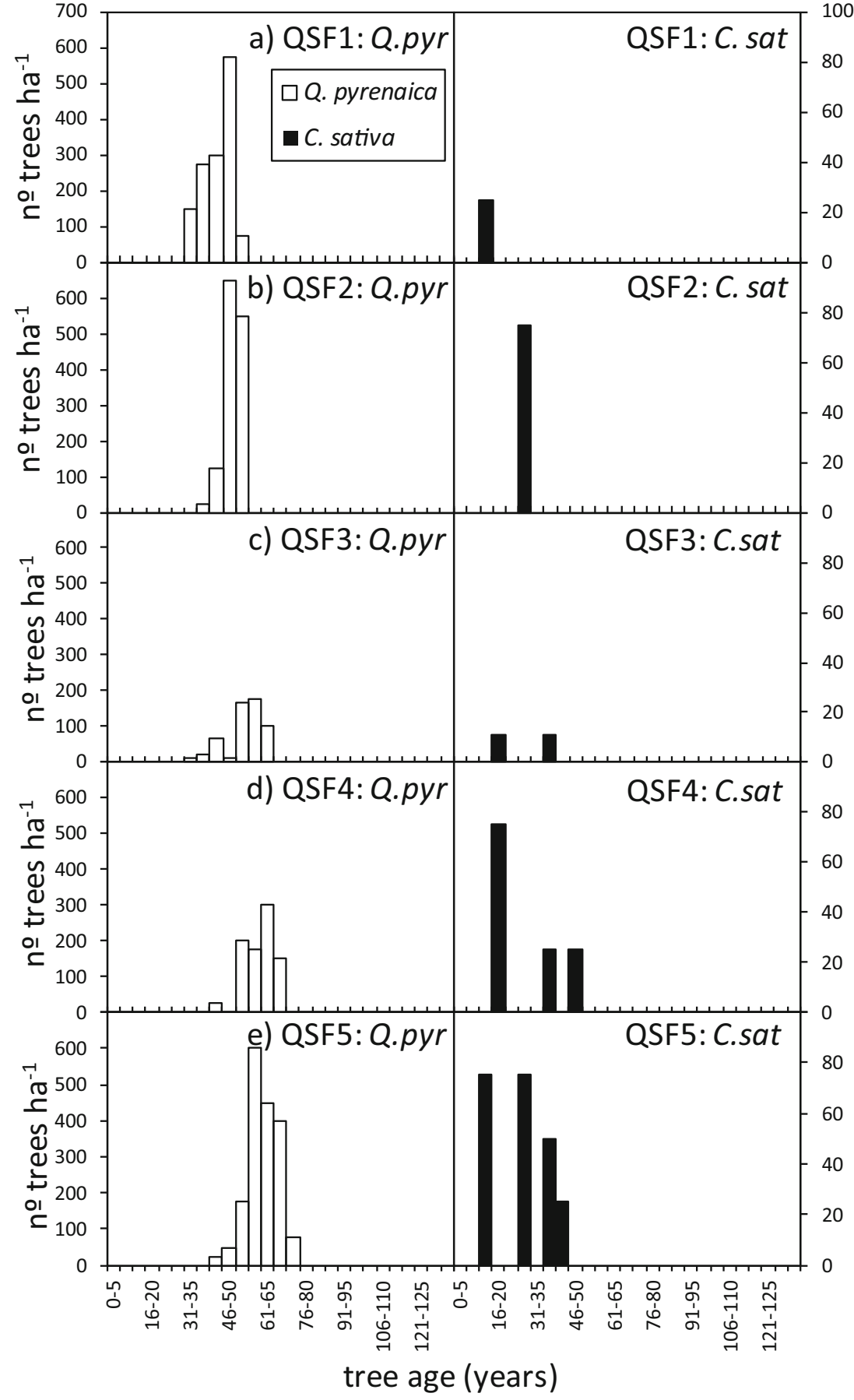

intermittent periods of high photon flux density that significantly improve carbon gain and hold a small positive carbon balance (Chazdon 1988; Way and Pearcy 2012), were occasionally recorded at CDF stands as short intervals (3-8 $\mathrm{min}$ ) of photon fluxes of $150-700 \mathrm{~mol} \mathrm{~m}^{-2} \mathrm{~s}^{-1}$ (data not shown). Thus, our data suggest that $C$. sativa can persist as advanced regeneration in the understory and can attain the main canopy layer throughout the gap regeneration phase of typical mature forests (Veblen 1992; Oliver and Larson 1996; Franklin et al. 2007).
By contrast, $Q$. pyrenaica, the main tree species in the study area, shows higher seedling regeneration than C. sativa in the QSF stands, but similar sapling density. This finding suggests lower shade tolerance than $C$. sativa and/or strong competition for water and nutrients between clones, as sprouting from lateral roots dominates $Q$. pyrenaica regeneration (Salomón et al. 2013; Camisón et al. 2015). However, the CDF stands show very little or no regeneration of $Q$. pyrenaica. Sexual reproduction is likely limited in 
Fig. 3 Age distributions in 5-year establishment classes of the CDF stands. Black solid bars: C. sativa total age; gray solid bars: C. sativa minimum ages; open bars: $Q$. pyrenaica; vertically hatched bars: $Q$. faginea; horizontally hatched bars: $I$. aquifolium; diagonally hatched bars: A. unedo; dotted bars: $P$. avium. Black arrows show the time of the synchronic radialgrowth releases of Fig. 4

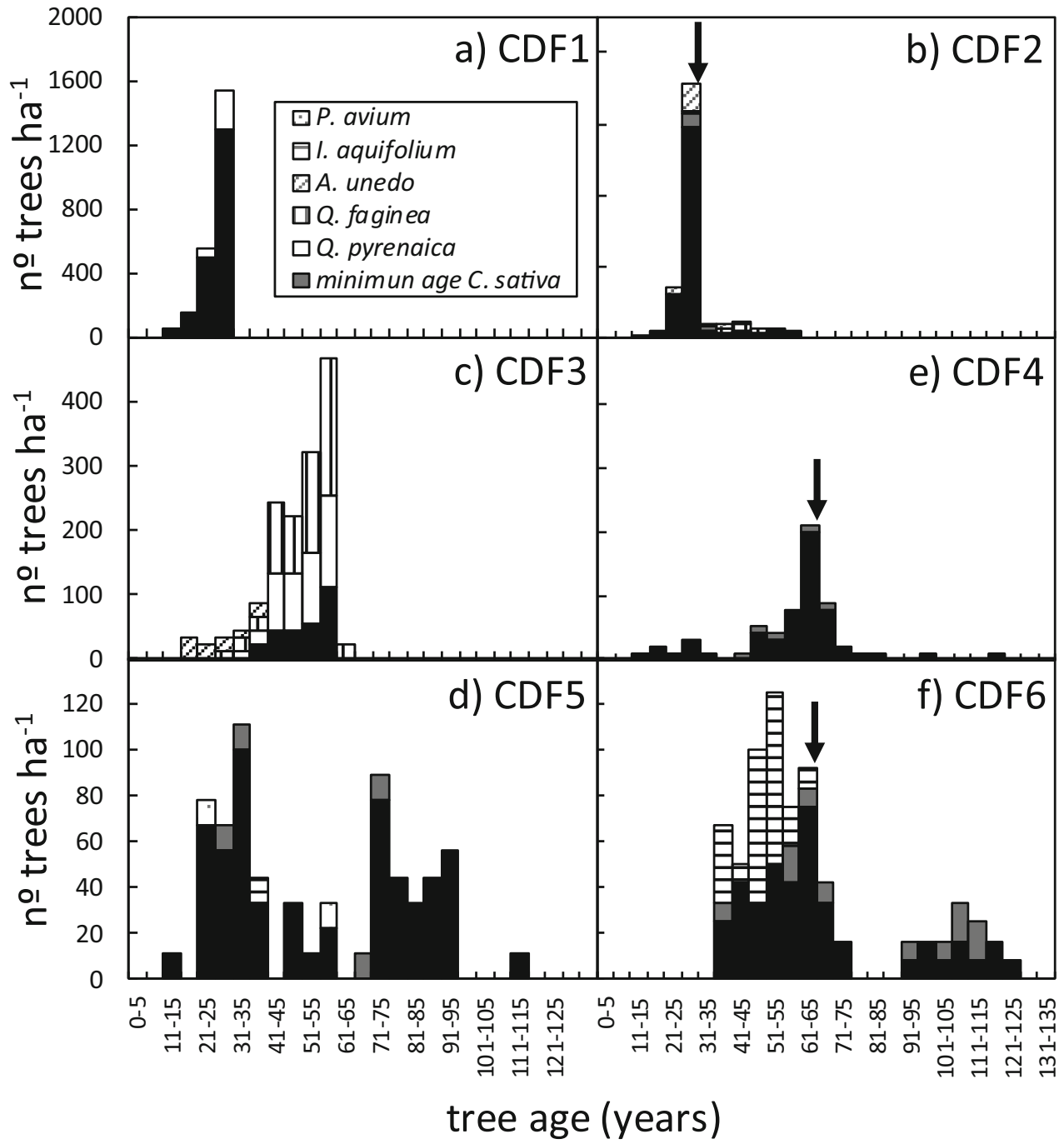

Q. pyrenaica due to a combination of factors such as low acorn production (Jiménez et al. 1998), high rates of acorn predation (Gómez et al. 2003), and low shade tolerance of the seedlings (Rodríguez-Calcerrada et al. 2007).

\subsection{C. sativa tree recruitment and mortality}

One of the more interesting findings of our study is the ability of $C$. sativa to recruit in QSF stands. Low tree density, a significant relationship between forest age and the number of $C$. sativa trees, nil chestnut mortality and the vigorous radial-growth of $C$. sativa trees indicate the potential for steadily increasing recruitment in our QSF stands. Although C. sativa is considered an intermediate shade-intolerant species at seedling/sapling stage (Pridnya et al. 1996; Pividori et al. 2005; Sevilla 2008; Zlatanov et al. 2013), light availability under the thin canopy of $Q$. pyrenaica allowed tree recruitment and a gradual transition to more natural mixed forests.

On the contrary, in CDF stands, $C$. sativa shows more complex tree dynamics that reflect past and diverse human intervention. The old forests, CDF4 and CDF6, show multiage stands and synchronic radial-growth release events that undoubtedly show signs of clear-cutting, and subsequent recruitment mainly because of sprouting (Cabanettes and Pagès 1992; Giudici and Zingg 2005). Old CDF5 shows asynchronous release patterns in $C$. sativa trees, which is consistent with minor-scale wood extraction and the small recruitment peaks of $C$. sativa and light-demanding Prunus avium (Stojecová and Kupka 2009). Low C. sativa mortality and the absence of effective recruitment of $Q$. pyrenaica is an indication of the resistance of $C$. sativa to competitive displacement during a short-medium successional time. As in the older stands, young coppices of $C$. sativa show strong recruitment (Giudici and Zingg 2005), as they sprout from stools after disturbances such as cutting (CDF1 and CDF3) or fire (CDF2). However, young mixed coppices show high non-random $C$. sativa mortality which highlights the importance of intra- and interspecific competition for limited resources. Departure from the random labeling model at short scales shows that stem mortality was not randomly 
Fig. 4 Annual radial-growth $(\mathrm{mm})$ of the main trees species in the study plots. Thick lines represent the mean ring growth and the thin lines indicate upper and lower standard error. Blue lines: $Q$. pyrenaica; red lines: C. sativa old cohort; dark red lines: C. sativa young cohort; green lines: $Q$. faginea. Black arrows indicate synchronic radialgrowth liberations in the older trees a) QSF1

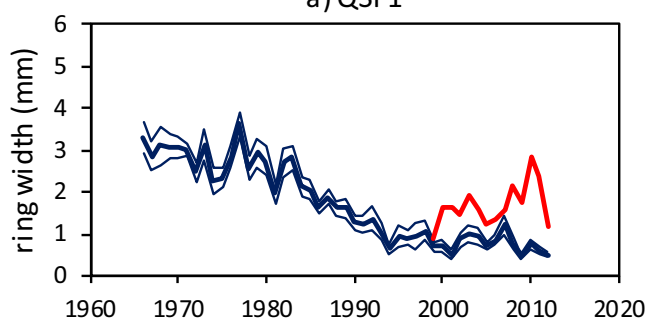

c) QSF3

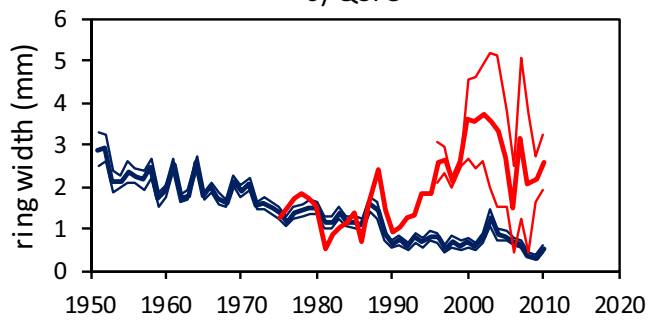

e) QSF5

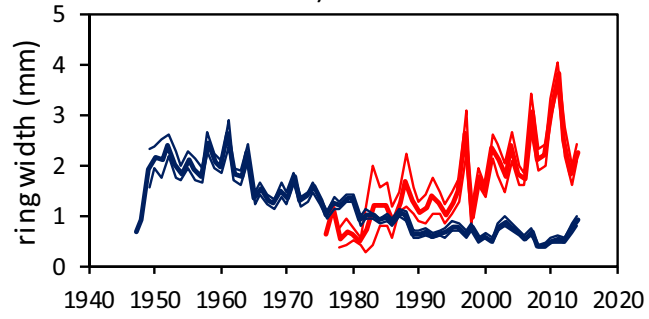

g) $\mathrm{CDF} 2$

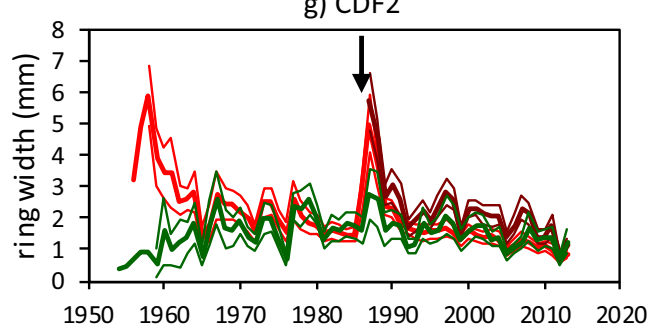

i) CDF4

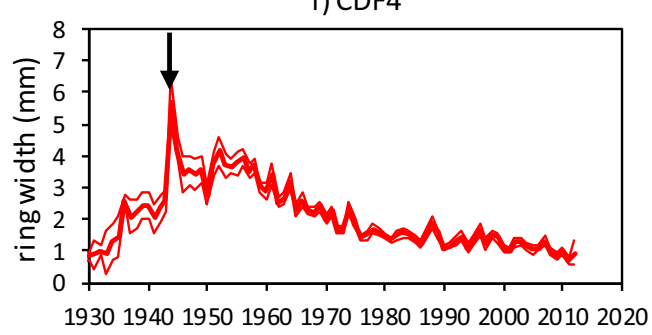

k) CDF6

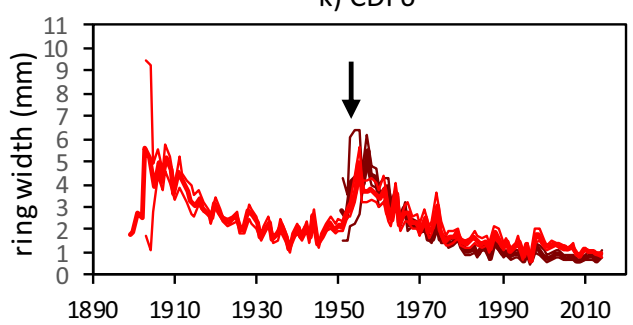

b) QSF2

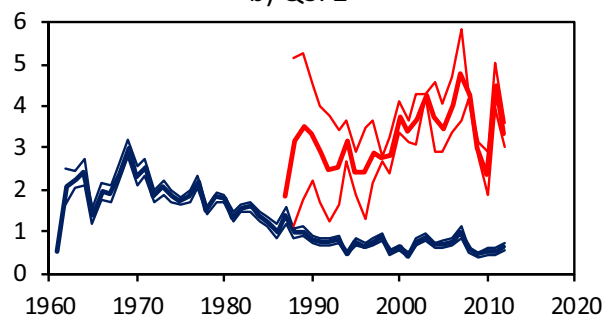

d) QSF4

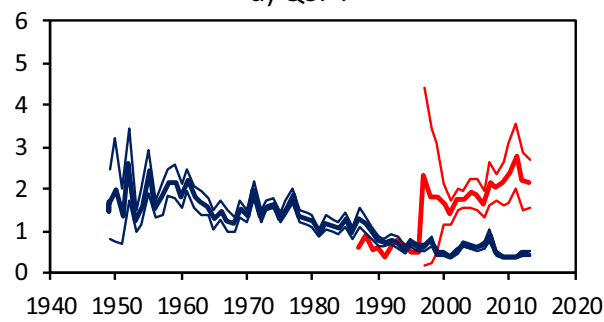

f) CDF1

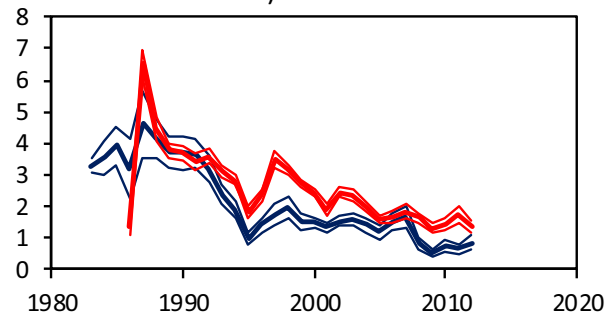

h) CDF3

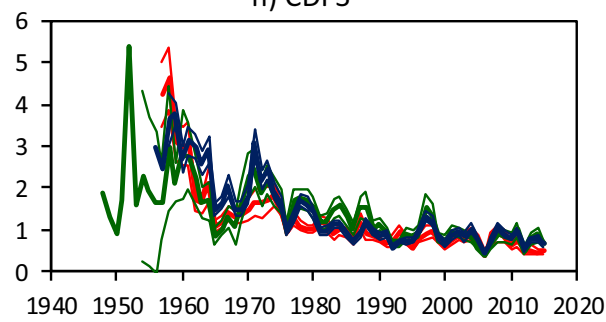

j) CDF5

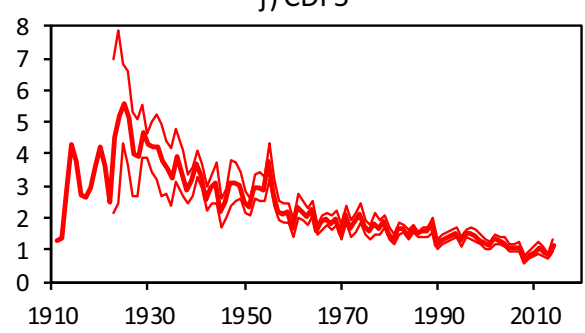

-C. sativa - young cohort C. sativa - old cohort Q. pyrenaica

\section{Q. faginea}

years 
Table 4 Results of the bivariate O-ring statistic for bivariate analysis

\begin{tabular}{|c|c|c|c|c|c|c|c|c|c|c|c|c|c|c|c|c|c|c|c|}
\hline \multirow[t]{2}{*}{ Sites } & \multirow[t]{2}{*}{ Point pattern } & \multirow[t]{2}{*}{ Model } & \multirow[t]{2}{*}{$P(0-10 \mathrm{~m})$} & \multirow[t]{2}{*}{ Rank } & \multicolumn{15}{|c|}{ Distance (m) } \\
\hline & & & & & 1 & 2 & 3 & 4 & 5 & 6 & 7 & 8 & 9 & 10 & 11 & 12 & 13 & 14 & 15 \\
\hline CDF1 & Cs saplings vs trees & Toroidal shift & 0.155 & 170 & $\mathrm{r}$ & $\mathrm{R}$ & $\mathrm{r}$ & $\mathrm{r}$ & $\mathrm{r}$ & r & $\mathrm{r}$ & $\mathrm{r}$ & $\mathrm{r}$ & $\mathrm{r}$ & & & & & \\
\hline CDF2 & Cs saplings vs trees & Toroidal shift & 0.135 & 174 & $\mathrm{r}$ & $\mathrm{R}$ & + & $\mathrm{r}$ & + & $\mathrm{r}$ & $\mathrm{r}$ & $\mathrm{r}$ & $\mathrm{r}$ & $\mathrm{r}$ & $\mathrm{r}$ & $\mathrm{r}$ & $\mathrm{r}$ & $\mathrm{r}$ & $\mathrm{r}$ \\
\hline CDF4 & Cs saplings vs trees & Toroidal shift & 0.670 & 66 & $\mathrm{r}$ & $\mathrm{R}$ & $\mathrm{r}$ & $\mathrm{r}$ & $\mathrm{r}$ & $\mathrm{r}$ & $\mathrm{r}$ & $\mathrm{r}$ & $\mathrm{r}$ & $\mathrm{r}$ & $\mathrm{r}$ & $\mathrm{r}$ & $\mathrm{r}$ & $\mathrm{r}$ & $\mathrm{r}$ \\
\hline CDF5 & Cs saplings vs trees & Toroidal shift & 0.120 & 170 & $\mathrm{r}$ & $\mathrm{R}$ & $\mathrm{r}$ & $\mathrm{r}$ & $\mathrm{r}$ & $\mathrm{r}$ & $\mathrm{r}$ & $\mathrm{r}$ & - & $\mathrm{r}$ & $\mathrm{r}$ & $\mathrm{r}$ & $\mathrm{r}$ & $\mathrm{r}$ & $\mathrm{r}$ \\
\hline CDF6 & Cs saplings vs trees & Toroidal shift & 0.220 & 157 & $\mathrm{r}$ & $\mathrm{R}$ & $\mathrm{r}$ & - & $\mathrm{r}$ & $\mathrm{r}$ & $\mathrm{r}$ & $\mathrm{r}$ & $\mathrm{r}$ & $\mathrm{r}$ & $\mathrm{r}$ & $\mathrm{r}$ & $\mathrm{r}$ & $\mathrm{r}$ & $\mathrm{r}$ \\
\hline CDF5 & Cs young vs old cohorts & Toroidal shift & 0.795 & 42 & $\mathrm{r}$ & $\mathrm{R}$ & $\mathrm{r}$ & $\mathrm{r}$ & $\mathrm{r}$ & $\mathrm{r}$ & $\mathrm{r}$ & $\mathrm{r}$ & $\mathrm{r}$ & $\mathrm{r}$ & $\mathrm{r}$ & $\mathrm{r}$ & $\mathrm{r}$ & $\mathrm{r}$ & $\mathrm{r}$ \\
\hline CDF6 & Cs young vs old cohorts & Toroidal shift & 0.035 & 194 & $\mathrm{r}$ & $\mathrm{R}$ & - & $\mathrm{r}$ & $\mathrm{r}$ & - & $\mathrm{r}$ & $\mathrm{r}$ & $\mathrm{r}$ & $\mathrm{r}$ & $\mathrm{r}$ & $\mathrm{r}$ & $\mathrm{r}$ & $\mathrm{r}$ & $\mathrm{r}$ \\
\hline CDF1 & Cs alive vs dead trees & Random labeling & 0.005 & 200 & - & - & $\mathrm{r}$ & $\mathrm{r}$ & $\mathrm{r}$ & $\mathrm{r}$ & $\mathrm{r}$ & $\mathrm{r}$ & $\mathrm{r}$ & $\mathrm{r}$ & & & & & \\
\hline CDF2 & Cs alive vs dead trees & Random labeling & 0.005 & 200 & - & - & - & - & - & - & - & - & - & - & - & - & - & $\mathrm{r}$ & $\mathrm{r}$ \\
\hline CDF3 & Cs alive vs dead trees & Random labeling & 0.010 & 199 & - & $\mathrm{R}$ & $\mathrm{r}$ & - & $\mathrm{r}$ & $\mathrm{r}$ & - & - & - & $\mathrm{r}$ & $\mathrm{r}$ & - & $\mathrm{r}$ & $\mathrm{r}$ & $\mathrm{r}$ \\
\hline CDF1 & Cs alive and dead trees vs other trees & Trivariate & & & $\mathrm{r}$ & $\mathrm{R}$ & $\mathrm{r}$ & $\mathrm{r}$ & r & $\mathrm{r}$ & $\mathrm{r}$ & $\mathrm{r}$ & $\mathrm{r}$ & $\mathrm{r}$ & & & & & \\
\hline CDF2 & Cs alive and dead trees vs other trees & Trivariate & & & $\mathrm{r}$ & $\mathrm{R}$ & $\mathrm{r}$ & $\mathrm{r}$ & $\mathrm{r}$ & $\mathrm{r}$ & $\mathrm{r}$ & - & $\mathrm{r}$ & - & - & - & - & - & - \\
\hline CDF3 & Cs alive and dead trees vs other trees & Trivariate & & & $\mathrm{r}$ & + & + & + & + & + & $\mathrm{r}$ & $\mathrm{r}$ & $\mathrm{r}$ & $\mathrm{r}$ & - & $\mathrm{r}$ & $\mathrm{r}$ & - & $\mathrm{r}$ \\
\hline
\end{tabular}

$P$ value of the goodness-of-fit (GoF) tests at distances of up to $10 \mathrm{~m}$ and rank of the pair correlation function after 199 iterations are shown. Statistical significance at $95 \%$ simulated envelopes: $(r)$ independent pattern; $(+)$ association pattern; $(-)$ repulsion pattern

distributed between stools, with some stools showing low mortality and others almost or completely dead, as found in other coppices undisturbed by human activities (Giudici and Zingg 2005). In addition, the trivariate analyses of the two coppices with the highest mortality show that $C$. sativa dead trees are less frequently far away from each other than what could be expected if they were randomly distributed. Also, they are more frequently closer to the live trees of other species. Hence, intraspecific competition at the stool level and interspecific competition with Quercus spp. and A. unedo sprouts play a role in the spatial pattern of $C$. sativa mortality. Although the trees did not show any sign of the characteristic signs of chestnut blight, such as pustules and cankers (Waldboth and Oberhuber 2009), we cannot discard the possibility that poor health conditions weaken chestnut trees pushing them toward mortality by tree competition. Chestnut trees with small leaves and dieback signs in the plot with the highest mortality provide some circumstantial evidence of ink disease, but more direct evidence through the pathogen isolation is needed (Vannini and Vettraino 2001; Juhásová and Bernadovicová 2001).

\subsection{Conclusions}

Our work clearly shows that $C$. sativa is able to recruit in secondary forests in the absence of forest management and cultural inputs. In the older chestnut-dominated stands, $C$. sativa shows certain resistance to competitive displacement, as the dominant species in the area, Q. pyrenaica, is unable to successfully become established. C. sativa seedling density is limited due to fruit production, but transition toward the sapling stage appears limited due to low light availability. By contrast, mixed young coppices of $C$. sativa show a high level of mortality and dieback, owing to competition with other vigorous resprouters.

Additionally, our results suggest that although $C$. sativa recolonizes after disturbances through sprouting, it maintains an advanced regeneration in mature forests and can also persist through a gap-phase mode of regeneration (sensu Veblen 1992). The replication of gap-forming processes through silvicultural management in closed forests could help to develop the horizontal and vertical structural heterogeneity typical of old-growth forests and facilitate the recruitment and selfreplacement of this iconic species of the European landscape (Zlatanov et al. 2015).

Acknowledgements We thank the staff forestry agency of the Regional Government of Castile \& Leon, especially Luis Carlos Jovellar, Alfonso Sarmiento, Ricardo Alonso-Bartol and Pedro Gómez, for the information and support provided during this study. The samples were collected under the Regional Government permits LASM/egc $(2012,2016)$. We are grateful to two anonymous reviewers for their helpful comments. $M^{a}$ Esther González and Emma Keck kindly corrected the English.

Funding This study was funded by research Grants for Master's projects administered by the Master's program in Biology and Conservation of Biodiversity of the University of Salamanca, Spain.

Statement on data availability The datasets generated and/or analyzed during the current study are available in the public repository Open Science Framework (https://osf.io/) (Silla 2018). Datasets not peerreviewed. Silla (2018) Dynamics and Regeneration of Chestnut forests. Version 31 Aug 2018. Open Science Framework. [Dataset]. https://doi. org/10.17605/OSF.IO/JRCFD 


\section{Compliance with ethical standards}

Conflict of interest The authors declare that they have no conflict of interest.

\section{References}

Altman J, Fibich P, Dolezal J, Aakala T (2014) TRADER: a package for tree ring analysis of disturbance events in R. Dendrochonologia 32: $107-112$

Amorini E, Chatziphilippidis G, Cianci O, Di Castri F, Giudici F, Leonardi S, Manetti MC, Nocentiin S, Pividori M, Rapp M, Romane F, Sevrin E, Zingg A (2000) Sustainability of chestnut forest ecosystems: is it possible? Ecol Mediterr 26:3-14

Cabanettes A, Pagès L (1992) Effet des techniques de coupe et des variations du milieu sur la croissance en hauteur des cépées dans un taillis de châtaignier (Castanea sativa). Can J For Res 22:1694 1700

Camisón A, Miguel R, Marcos JL, Revilla J, Tardáguila M, Hernández D, Lakicevic M, Jovellar L, Silla F (2015) Regeneration dynamics of Quercus pyrenaica Willd. in the central system (Spain). For Ecol Manag 343:42-52

Chazdon R (1988) Sunflecks and their importance to forest understory plants. Adv Ecol Res 18:1-63

Conedera M, Krebs P (2008) History, present situation and perspective of chestnut cultivation in Europe. Acta Hortic 784:23-27

Conedera M, Stanga P, Lischer C, Stöckli V (2000) Competition and dynamics in abandoned chestnut orchards in southern Switzerland. Ecol Mediterr 26:101-112

Conedera M, Stanga P, Oester B, Bachmann P (2001) Different postculture dynamics in abandoned chestnut orchards and coppices. For Snow Landsc Res 76:487-492

Conedera M, Krebs P, Tinner W, Pradella M, Torriani D (2004) The cultivation of Castanea sativa (mill.) in Europe, from its origin to its diffusion on a continental scale. Veget Hist Archaeobot 13:161169

Conedera M, Tinner W, Krebs P, de Rigo D, Caudullo G (2016) Castanea sativa in Europe: distribution, habitat, usage and threats. In: SanMiguel-Ayanz J, de Rigo D, Caudullo G, Houston Durrant T, Mauri A (eds) European Atlas of Forest Tree Species. Publ. Off. EU, Luxembourg, $\mathrm{p}$ e0125e $0+$

Cutini A (2001) New management options in chestnut coppices: an evaluation on ecological bases. For Ecol Manag 141:165-174

De la Cruz M, Romao RL, Escudero A, Maestre FT (2008) Where do seedlings go? A spatio-temporal analysis of seedling mortality in a semi-arid gypsophyte. Ecography 31:1-11

Diggle PJ (2003) Statistical analysis of spatial point patterns. Arnold, London

Dirección General de Montes, Caza y Pesca Fluvial (1967) Proyecto de Ordenación definitiva del monte $\mathrm{n}^{\circ} 80$ del Catálogo de UP de esta provincia, denominado "Dehesa, Sierra Mayor, Honfrías, Coquilla, Mata Corcera y Majada Llana" sito en el término municipal de Linares de Riofrío (Salamanca). Ministerio de Agricultura, Distrito Forestal de Salamanca

Duncan RP (1989) An evaluation of errors in tree age estimates based on increment cores in kahikatea (Dacrycarpus dacrydioides). NZ Nat Sci 16:31-37

Fineschi S, Taurchini D, Villani F, Vendramin GG (2000) Chloroplast DNA polymorphism reveals little geographical structure in Castanea sativa mill. (Fagaceae) throughout southern European countries. Mol Ecol 9:1495-1503
Franklin JF, Mitchell R, Palik B (2007) Natural disturbance and stand development principles for ecological forestry. General Technical Report NRS-19, USDA Forest Service

Gallardo JF (2001) Distribution of chestnut (Castanea sativa Mill.) forests in Spain: possible ecological criteria for quality and management (focusing on timber coppices). For Snow Landsc Res 76:477481

García P, Monte E (2005) Fitopatología del Castaño. El Chancro y la Tinta en la Provincia de Salamanca. AGRO Interreg IIIB. Espacio Atlántico. DPS - OAEDR - FEDER

Gilland KE, Keiffer CH, McCarthy BC (2012) Seed production of mature forest-grown American chestnut (Castanea dentata (Marsh.) Borkh). J Torrey Bot Soc 139:283-289

Giudici F, Zingg A (2005) Sprouting ability and mortality of chestnut (Castanea sativa mill.) after coppicing. A case study. Ann For Sci 62:513-523

Gómez JM, García D, Zamora R (2003) Impact of vertebrate acorn- and seedling-predators on a Mediterranean Quercus pyrenaica forest. For Ecol Manag 180:125-134

Holmes RL (1983) Computer-assisted quality control in tree-ring dating and measurement. Tree-Ring Bull 43:69-78

Holyoak D (1968) A comparative study of the food of some British corvidae. Bird Study 15:147-153

Jiménez MPS, Fernández PMD, Albertos SM, Sánchez LG (1998) Regiones de procedencia de Quercus pyrenaica Willd. Quercus faginea Lam, Quercus canariensis Willd. OAPN, Madrid

Juhásová G, Bernadovicová S (2001) Cryphonectria parasitica (Murr.) Barr and Phytophthora spp. in chestnut (Castanea sativa mill.) in Slovakia. For Snow Landsc Res 76:373-377

Krebs CJ (1999) Ecological methodology, second ed. Addison-Wesley Educational Publishers, Inc

Krebs P, Conedera M, Pradella M, Torriani D, Felber M, Tinner W (2004) Quaternary refugia of the sweet chestnut (Castanea sativa mill.): an extended palynological approach. Veget Hist Archaeobot 13:145160

Loosmore NB, Ford ED (2006) Statistical inference using the G or K point pattern spatial statistics. Ecology 87:1925-1931

Milgroom MG, Cortesi P (2004) Biological control of chestnut blight with hypovirulence: a critical analysis. Annu Rev Phytopathol 42: 311-338

Morales-Molino C, Vescovi E, Krebs P, Carlevaro E, Kaltenrieder P, Conedera M, Tinner W, Colombaroli D (2015) The role of humaninduced fire and sweet chestnut (Castanea sativa mill.) cultivation on the long-term landscape dynamics of the southern Swiss Alps. Holocene 25:482-494

Mujic I, Alibabic V, Zǐvkovic J, Jahic S, Jokic S, Prgomet Z, Tuzlak Z (2010) Morphological characteristics of chestnut Castanea sativa from the area of Una- Sana canton. J Cent Eur Agric 11:185-190

Nowacki GJ, Abrams MD (1997) Radial-growth averaging criteria for reconstructing disturbance histories from presettlement-origin oaks. Ecol Monogr 67:225-249

Oliver CD, Larson BC (1996) Forest stand dynamics, updated ed. McGraw Hill, New York

Pividori M, Armando F, Conedera M (2005) Post cultural dynamics in a mixed chestnut coppice at its ecological border. Acta Hort: Proc III Intl Chestnut Congress 693:219-224

Pridnya M, Cherpakov V, Paillet F (1996) Ecology and pathology of European chestnut (Castanea sativa) in the deciduous forests of the Caucasus mountains in southern Russia. Bull Torrey Bot Club $123: 213-222$

R Core Team (2013). R: A language and environment for statistical computing. R Foundation for Statistical Computing, Vienna, Austria. http://www.R-project.org/. Accessed date: 25 July 2018

Robin C, Morel O, Vettraino AM, Perlerou C, Diamandis S, Vannini A (2006) Genetic variation in susceptibility to Phytophthora 
cambivora in European chestnut (Castanea sativa). For Ecol Manag 226:199-207

Rodríguez-Calcerrada J, Pardos JA, Gil L, Aranda I (2007) Acclimation to light in seedlings of Quercus petraea (Mattuschka) Liebl. and Quercus pyrenaica Willd. planted along a forest-edge gradient. Trees 21:45-54

Salomón R, Valbuena-Carabaña M, Gil L, González-Doncel I (2013) Clonal structure influences stem growth in Quercus pyrenaica Willd. coppices: bigger is less vigorous. For Ecol Manag 296:108118

San Roman Sanz A, Fernandez C, Mouillot F, Ferrat L, Istria D, Pasqualini V (2013) Long-term forest dynamics and land-use abandonment in the Mediterranean mountains, Corsica, France. Ecol Soc 18:38

Scarascia-Mugnozza G, Oswald H, Piussi P, Radoglou K (2000) Forest of the Mediterranean region: gaps in knowledge and research needs. For Ecol Manag 132:97-109

Seijo F, Millington J, Gray R, Sanz V, Lozano J, García-Serrano F, Sangüesa-Barreda G, Camarero JJ (2015) Forgetting fire: traditional fire knowledge in two chestnut forest ecosystems of the Iberian Peninsula and its implications for European fire management policy. Land Use Policy 47:130-144

Sevilla F (2008) Una teoría ecológica para los bosques ibéricos. Junta de Castilla y León. In: León

Silla (2018) Dynamics and Regeneration of Chestnut forests [Dataset]. Version 31 Aug 2018. Open Science Framework. https://doi.org/10. 17605/OSF.IO/JRCFD. Accessed date: 25 July 2018

Stojecová R, Kupka I (2009) Growth of wild cherry (Prunus avium L.) in a mixture with other species in a demonstration forest. J For Sci 55: 264-269
Stokes MA, Smiley TL (1968) An introduction to tree-ring dating. The University of Chicago Press, Chicago

Urbisz A, Urbisz A (2007) European chestnut (Castanea sativa Mill.) - a tree naturalized on the Baltic Sea coast? Pol J Ecol 55:175-179

Vander Wall SB (2001) The evolutionary ecology of nut dispersal. Bot Rev 67:74-118

Vannini A, Vettraino AM (2001) Ink disease in chestnuts: impact on the European chestnut. For Snow Landsc Res 76:345-350

Veblen TT (1992) Regeneration dynamics. In: Glenn-Lewin DC, Peet RK, Veblen TT (eds) Plant succession: theory and prediction. Chapman and Hall, London, pp 152-187

Waldboth M, Oberhuber W (2009) Synergistic effect of drought and chestnut blight (Cryphonectria parasitica) on growth decline of European chestnut (Castanea sativa). For Path 39:43-55

Way DA, Pearcy RW (2012) Sunflecks in trees and forests: from photosynthetic physiology to global change biology. Tree Physiol 32: 1066-1081

Wiegand T, Moloney KA (2014) Handbook of spatial point-pattern analysis in ecology. CRC Press, Boca Raton

Zamora P, Martin AB, Rigling D, Diez JJ (2012) Diversity of Cryphonectria parasitica in western Spain and identification of hypovirus-infected isolates. For Pathol 42:412-419

Zlatanov T, Schleppi P, Velichkov I, Hinkov G, Georgieva M, Eggertsson O, Zlatanova M, Vacik H (2013) Structural diversity of abandoned chestnut (Castanea sativa Mill.) dominated forests: implications for forest management. For Ecol Manag 291:326-335

Zlatanov T, Velichkov I, Georgieva M, Hinkov G, Zlatanova M, Gogusev G, Eastaugh CS (2015) Does management improve the state of chestnut (Castanea sativa L) on Belasitsa Mountain, southwest Bulgaria? iForest 8:860-865 